\title{
Biophysical Overview of Covid-19 Infection
}

\author{
Covid-19 Enfeksiyonuna Biyofiziksel Genel Bakıs
}

\author{
Denizhan Karis', Damla Anbarli Metin', Feride Fulya Ercan Coskun ${ }^{3}$, Aylin Koseler ${ }^{4}$ \\ ${ }^{1}$ Department of Biophysics, Faculty of Medicine, Istinye University, Istanbul; ${ }^{2}$ Department of Emergency, Faculty of Medicine, Karabuk \\ University, Karabuk; ${ }^{3}$ Department of Emergency, Cigili Education and Research Hospital, Faculty of Medicine, Bakircay University, \\ Izmir; ${ }^{4}$ Department of Biophysics, Faculty of Medicine, Pamukkale University, Denizli, Turkey
}

\begin{abstract}
Severe acute respiratory syndrome coronavirus 2 (SARS-CoV-2) infection was declared a global pandemic by WHO on March 11, 2020. Coronavirus disease (COVID-19) is the infectious disease caused by SARS-CoV-2. It is transmitted from person to person through droplets, progresses asymptomatically in $70 \%$ of the sufferers, while it may manifest itself in severe clinical conditions, ranging from viral upper respiratory tract infection to pneumonia, sepsis, septic shock, and even acute respiratory distress syndrome (ARDS), in symptomatic patients. Studies on the epidemiological and clinical features of COVID-19 have shown that these patients can develop symptoms of mild or severe acute respiratory infection. In cases with mild symptoms, upper respiratory tract symptoms such as fever, dry cough, and fatigue may develop, and abnormal chest CT findings may also be present. In cases with severe symptoms, dyspnea, diarrhea, severe pneumonia, ARDS or multiple organ failure develop, and mortality rates vary between $4.3 \%$ and $15 \%$ according to different study reports.
\end{abstract}

Key words: COVID-19; hemorheology; respiratory system; body fluids; oxidative stress; sedantary life

\begin{abstract}
ÖZET
Șiddetli akut solunum sendromu koronavirüs 2 (SARS-CoV-2) enfeksiyonu, 11 Mart 2020 tarihinde DSÖ tarafindan küresel bir pandemi ilan edilmiștir. Koronavirüs hastalığı (COVID-19), SARS-CoV-2'nin neden olduğu bulașıcı hastalıktır. Damlacık yoluyla kișiden kișiye bulașan SARS-CoV-2 enfeksiyonu, hastaların \%70'inde asemptomatik olarak görülmektedir. Semptomatik hastalarda ise viral üst solunum yolu enfeksiyonundan pnömoni, sepsis, septik șok ve hatta akut solunum sıkıntısı sendromuna (ARDS) kadar değișen ciddi klinik durumlarla seyredebilmektedir. COVID-19'un epidemiyolojik ve klinik özellikleri üzerine yapılan çalıșmalarda, bu hastalarının hafif veya șiddetli akut solunum yolu enfeksiyonu semptomları geliștirebileceğini gösterilmiștir. Hafif semptomları olan olgularda ateș, kuru öksürük, yorgunluk gibi üst solunum yolu semptomları gelișebilir ve anormal göğüs BT bulguları da olabilir. Farklı çalıșma raporlarına göre, șiddetli semptomları olan vakalarda nefes darlığı, ishal, șiddetli pnömoni, ARDS veya çoklu organ yetmezliği gelișmekte ve ölüm oranları \%4,3 ile \%15 arasında değișmektedir.
\end{abstract}

Anahtar kelimeler: COVID-19; hemreoloji; solunum sistemi; vücut sIvIlarl; oksidatif stres; sedanter yașam

\section{Introduction}

Coronavirus Disease 2019 (COVID-19) is a very contagious viral disease that has spread globally resulting in high morbidity and mortality rates. Comorbidities like pulmonary or cardio-vascular diseases (CVD), diabetes, immune system disorders and older age deteriorate the clinical onset. After being activated by spike protein, the virus binds to human angiotensin-converting enzyme 2 (ACE2) receptor. ACE2, expressed mainly in lungs, also in heart, kidneys, and vascular endothelial tissue, is excessively activated in CVD and has been reported to be one of the responsible causes for the multiple organ failure in COVID-19 ${ }^{1}$.

\section{Biophysical Effects of COVID-19 on Hemoreologic Parameters}

Inflammation status in COVID-19 triggers myocardial injury via increases in serum levels of troponin and also in inflammatory bio-markers like CRP, ferritin, fibrinogen, D-dimer, IL-6, and LDH, all acting preliminarily for the cytokine storm. Fibrinogen, one of the most important determinants of plasma viscosity (PV) with its big molecular structure and asymmetry, increases extensively in plasma of COVID-19 patients. Fibrinogen's pivotal function in coagulation is even to constitute a clot in vessel injuries for stopping the bleeding or to aggrevate thrombosis during inflammatory process. Clinical onset of thrombosis seen in COVID-19 can be followed up via plasma fibrinogen and D-dimer levels, which is a degradated product of cross-linked fibrin ${ }^{2}$. Consequently, blood viscosity (BV) also increases due to elevated levels of

Iletișim/Contact: Aylin Köseler, Pamukkale University Faculty of Medicine, Department of Biophysics, Denizli, Turkey • Tel: 05336122477 • E-mail:aylinkoseler@gmail.com • Geliș/Received:07.08.2021 • Kabul/Accepted: 14.10.2021

ORCID: Denizhan Karış, 0000-0002-5976-4107 • Damla Anbarlı Metin, 0000-0001-9873-4587 •

Feride Fulya Ercan Coskun, 0000-0002-1514-6729 • Aylin Köseler, 0000-0003-4832-0436 
acute phase reactants and immunoglobulins via inflammatory process. Elevated fibrinogen, PV and BV foster erythrocyte aggregation that ends up in higher erythrocyte sedimentation rate r $^{3}$.

Another target of COVID-19 is the endothelial tissue, that consitutes the largest tissue in human body. Endothelial dysfuction accompanied with generalized inflammation may lead to pro-coagulative state resulting in micro-vascular and macro-vascular thrombosis in arterial and venous circulation ${ }^{2,4}$. COVID-19 clinical onset have to be evaluated with a multi-disciplinary approach, especially in CVD by means of cardiovascular co-morbidities and hemorheological parameters. More scientific data should be elucidated to determine the mechanisms of cardio-vascular system and its complications in order to minimize morbidity and mortality rates.

\section{Biophysical Effects of COVID-19 on Respiratory System}

COVID-19 effects generally respiratory system besides with cardiovascular and immune systems. As the virus enters mostly via nose and conducting airways, respiratory droplets reach to alveoli ${ }^{5}$. Alveolar wall (AW) thickens due to oxidative stress, inflammation, secreted cytokines, endothelial dysfunction and increased permeability resulting in fibrosis of alveolocapillary membrane (ACM). Leakage of serum proteins and formation of fibrin exudates into alveolar space induces alveolar flooding and deteriorates surfactant production from alveolar type II cells $s^{6}$. Phospholipid content of pulmonary surfactant is responsible for lowering the surface tension of alveoli during inspiration and for inhibiting alveolar collapse (AC) after expiration ${ }^{6,7}$. Surfactant dysfunction of injured alveoli terminates in increased intraalveolar pressure (AP) and transmural tension according to LaPlace Law. Besides, gas diffusion rate across ACM slows down due to diminished partial pressure of oxygen $\left(\mathrm{PaO}_{2}\right)$ and thickened AW as described by Fick's $\mathrm{Law}^{7,8}$. Ventilation in lungs occurs because of a pressure gradient between atmospheric pressure and intraalveolar pressure (AP) ${ }^{9}$. Fluid adhesion and negative pressure hold visceral and parietal pleura attached to each other. When parietal movement of thorax cavity pulls the lungs encovered with pleural layers (PL), diaphragm muscle contracts, the lungs expand, thorax volume increases and intrathoracic pressure decreases during inhalation due to Boyle's Law ${ }^{8,9}$. Pleural fluid is a viscous fluid that fills pleural cavity allowing PL to glide over each other. Negative intrapleural pressure is controlled by hydrostatic and oncotic pressures. Pleural layers are thickened probably followed by pleural effusion in severe COVID-199,10. Gas exchange (GE) in central and peripheral body sites gets disturbed resulting in decreased $\mathrm{PaO}_{2}$ described with Dalton's Law ${ }^{4,5}$. These mentioned pathologic alterations induce $\mathrm{AC}$ and impaired $\mathrm{GE}$ in a vicious cycle of hypoxia and acute respiratory distress syndrome. Evaluation of respiratory and cardiovascular systems within the basis of gas laws and body fluids should be considered for diagnosis, treatment and follow-up of COVID-19 patients.

\section{Biophysical Effects of COVID-19 on Body Fluids}

Transmission of COVID-19 mainly occurs via respiratory droplets firstly targeting both upper and lower respiratory tracts. As COVID-19 virus reaches to terminal bronchi and alveoli, its spike protein binds to alveolar type-2 cells (AT2) by angiotensin converting enzyme-2 receptors. Encountering of viral burden with host cells and cell membranes induces inflammatory signals that are secreted from AT2 recruiting neutrophils and macrophages to infection site ${ }^{1}$. Neutrophil infiltration acts as the first defense mechanism and secrete reactive oxygen species (ROS) to destroy infected cells. Macrophages secrete many cytokines that recruit immune cells to infection site. Activated neutrophils and macrophages, and released cytokines are the chief factors that trigger the inflammatory response in COVID-19 infection via vasodilation, leakage in capillaries and thickening of alveolar membrane ${ }^{11,12}$. Endothelial cells are the other target for COVID-19 virus effected from increased local blood pressure and weakening of cell junctions, resulting in injured basal membrane. Intravascular fluid transfers through these leakage areas leading to interstitial oedema encircling both capillaries and alveoli. Inflammation originated from activated immune system and ROS-induced mechanisms transform the alveolar membrane into a thickened surface. Surfactant secreted from AT2 is diluted because of intra-alveolar fluid and surfactant synthesis is deteriorated due to inflammation and oedema conditions $^{4,13}$. As infection gets more severe, intra-alveolar fluid becomes more infectious rich in protein, which also retracts fluid from intravascular compartment into interstitial space. Vasodilatation, injured basal membrane and cytokine storm trigger endothelial 
dysfunction in respiratory capillaries leading to uncontrolled clotting and thrombosis. Thrombosis is not just limited in respiratory system, the whole circulatory system becomes under threat for thrombosis including additional clotting factors and platelets ${ }^{4,14}$. This mentioned issues induce alveolar collapse, increased permeability in capillaries, pulmonary oedema and impaired gas exchange resulting in a vicious cycle of hypo-oxygenation and respiratory distress syndrome ${ }^{15}$. Body fluids, endothelial dysfunction and gas exchange within an aspect of biophysical evaluation should be considered thoroughly in diagnosis, treatment and follow-up of COVID-19 infection.

\section{Biophysical Effects of COVID-19 on Oxidative Stress}

COVID-19 is a viral infection caused by a RA virus disturbing many human body systems, especially the respiratory system ${ }^{16}$. Respiratory viral infections induce lipid and protein peroxidation, cytokine and chemokine production, inflammation and cell death. High burden of reactive oxygen species (ROS) and free radicals (FR) are produced from pathologic processes metabolic reactions in COVID-19 infec$\operatorname{tion}^{17,18}$. Oxidative stress (OS) is described as the imbalance of pro-oxidant and anti-oxidant systems due to increase in pro-oxidants, resulting in ROS production and cell damage ${ }^{19}$. OS status can be tolerated by anti-oxidant defense mechanisms including many enzymes, co-factors, vitamins, minerals and trace elements. These anti-oxidant substances scavange the harmful effects ROS and FR in order to maintain the physiological metabolism of biomolecules like DNA, RNA, proteins, carbohydrates and lipids ${ }^{20}$. If the optimum physiological metabolism cannot be achieved, pro-oxidants would promote a proinflammatory environment including biochemical, biophysical, biomolecular and nuclear pathways ${ }^{18}$. This physiopathological scenario is similar by means of COVID-19 infection. The vulnerable point of COVID-19 infection is that little data have been elucidated yet related with this disease. A destructive over-reaction in immune system called as "cytokine storm" stimulates the over-production of inflammation markers closely in relation with ROS and FR. An uncontrolled generalized immune response plays the leading role for COVID-19 infection in many systems of the body, primarily in respiratory system $^{21}$. COVID-19 infected individuals who have comorbidities such as hypertension, diabetes, obesity and cardiocerebrovascular diseases are at more risk for $\mathrm{OS}^{18}$. Oxidative stress is accepted as a probable cause associated with clinical onset of COVID-19. Oxidative stress can be reduced by endogenous antioxidant enzymes and molecules like glutathione, and exogenous supplementation of zinc, selenium, and vitamin $\mathrm{C}$, vitamin $\mathrm{D}$, vitamin $\mathrm{E}$.

\section{Effects of COVID-19 on Sedantary Life, Circulatory and Pulmonary Dynamics}

COVID-19 presents a life-altering challenge for all population that forces all the individuals to live selfisolated in home-confinement. Biological systems such as cardiovascular, pulmonary and muscular systems are effected from this sedentary life style ${ }^{5,22}$. Muscle contractions in lower extremities during physical exercise pumps the burden of blood in venous system back to the right auricula in the heart. On the other hand, diminished physical activity and physical inactivity may promote the stasis of blood in lower extremities resulting in thrombosis ${ }^{23}$. Muscle loss as a result of physical inactivity has a close relationship with microvascular alterations, lowered aerobic capacity, fat deposits in the body, insulin resistance and inflammation ${ }^{5,22}$. A combination of a diet rich in fatty acids and physical inactivity induces insulin resistance observed in dysfunctions of skeletal muscle tissue $^{24}$. Moreover, apetite changes prone to eating more creates a psychological pathology that would induce over-weight individuals having increased rates of metabolic and cardiovascular risk. Increased habit of smoking and/or alcohol abuse in home-confinement interval may change the individual's and the family's life style and may have effects over entire public ${ }^{25}$. A regularly planned physical exercise was accepted to lower the risk factors such as high body fat, dyslipidemia, atherosclerosis, thromboembolism and stroke ${ }^{22,23}$. All issues mentioned above cause burden of oxidative stress and pro-inflammatory process probably resulting in cardiocerebrovascular diseases. Home-based exercises including streching-relaxation exercises, stepping, self exercises utilizing virtual programs and breathing exercises possibly assisted with wearable technologies would be life-saving for conserving cardiovascular, pulmonary and muscular health during isolation period due to social distancing. Another crucial issue is that individuals should organize their daily lives within a plan covering the regulation of diet and calorie restriction. 


\section{Conclusion}

The present study is a brief and simple summary for the biophysical effects of COVID-19 on various biological systems. These effects possess a clinical manifestation of the infection and its complications in the metabolism. However, there is an urgent need for the introduction of the whole molecular, cellular dynamics of this trial with its clinical effects on the systems. We consider that in the future, with the availability of such quantitative data, functional the effect of COVID-19 infection on biological systems will be elucidated.

\section{References}

1. Wang X, Fang X, Cai Z, Wu X, Gao X, Min J et al. Comorbid chronic diseases and acute organ injuries are strongly correlated with disease severity and mortality among COVID-19 patients: A systemic review and meta-analysis. Research (Wash D C) 2020;19:2402961.

2. Ahmed S, Zimba O, Gasparyan AY. Thrombosis in coronavirus disease 2019(COVID-19)through the prism of Virchow's triad. Clin Rheumatol 2020;39:2529-43.

3. Baskurt O. Pathophysiological significance of blood rheology. Turk J Med Sci 2003;33(6):347-55.

4. Grobler C, Maphumulo SC, Grobbelaar LM, Bredenkamp JC, Laubscher GJ, Lourens PJ, et al. Covid-19: The rollercoaster of fibrin (Ogen), D-dimer, von willebrand factor, p-selectin and their interactions with endothelial cells, platelets and erythrocytes. Int J Mol Sci 2020;21(14):5168.

5. Ge H, Wang X, Yuan X, Xiao G, Wang C, Deng T et al. The epidemiology and clinical information about COVID-19, Eur J Clin Microbiol Infect Dis 2020;39(6):1011-19.

6. Mason RJ. Thoughts on the alveolar phase of COVID-19. Am J Physiol Lung Cell Mol Physiol 2020;1;319(1): L115-20.

7. Ghati A, Dam P, Tasdemir D, Kati A, Sellami H, Sezgin GC et al. Exogenous pulmonary surfactant: A review focused on adjunctive therapy for severe acute respiratory syndrome coronavirus 2 including SP-A and SP-D as added clinical marker. Curr Opin Colloid Interface Sci 2020;51:101413.

8. Holbrow CH, Lloyd JN, Amato JC, Galvez E, Parks ME. Gas laws. In: Modern introductory physics, New York: Springer, 2010:83-108.

9. Guyton AC, Hall JE. Guyton and Hall textbook of medical physiology, 12nd ed. Philadelphia, Pennsylvania: Elsevier Inc, 2012.

10. Feller-Kopman, D, Light R. Pleural disease. N Engl J Med 2008;378(8):740-51.

11. Chiang CC, Korinek M, Cheng WJ, Hwang TL. Targeting neutrophils to treat acute respiratory distress syndrome in coronavirus disease. Front Pharmacol 2020;11:572009.
12. Leth-Larsen R, Zhong F, Chow VT, Holmskov U, Lu J. The SARS coronavirus spike glycoprotein is selectively recognized by lung surfactant protein $\mathrm{D}$ and activates macrophages. Immunobiology 2007;212(3):201-11.

13. Suzuki YJ, Nikolaienko SI, Dibrova VA, Dibrova YV, Vasylyk VM, Novikov MY et al. SARS-CoV-2 spike proteinmediated cell signaling in lung vascular cells. Vasc Pharmacol 2020;137:106823.

14. Sardu C, Gambardella J, Morelli MB, Wang X, Marfella R, Santulli G. Hypertension, thrombosis, kidney failure, and diabetes: Is COVID-19 an endothelial disease? A comprehensive evaluation of clinical and basic evidence. J Clin Med 2020;11;9(5):1417.

15. Matthay, MA, Zimmerman GA. Acute lung injury and the acute respiratory distress syndrome: four decades of inquiry into pathogenesis and rational management. Am J Respir Cell Mol Biol 2005;33(4), 319-27.

16. Ntyonga-Pono MP. COVID-19 infection and oxidative stress: an underexplored approach for prevention and treatment? Pan Afr Med J 2020;35(Supp 2):12.

17. Sies H, Berndt C, Jones DP. Oxidative Stress. Annu Rev Biochem 2017;86:715-48.

18. Delgado-Roche L, Mesta F. Oxidative stress as key player in severe acute respiratory syndrome coronavirus (SARS-CoV) infection. Arch Med Res 2020;51(5):384-7.

19. Pizzino G, Irrera N, Cucinotta M, Pallio G, Mannino F, Arcoraci $\mathrm{V}$ et al. Oxidative stress: Harms and benefits for human health. Oxid Med Cell Longev 2017:8416763.

20. Keshari AK, Verma AK, Kumar T, Srivastava R. Oxidative stress: A review. Int J Sci Environ Technol 2015;3(7):155-62.

21. Coperchini F, Chiovato L, Croce L, Magri F, Rotondi M. The cytokine storm in COVID-19: An overview of the involvement of the chemokine/chemokine-receptor system. Cytokine Growth Factor Rev 2020;53:25-32.

22. Narici M, De Vito G, Franchi M, Paoli A, Moro T, Marcolin G. Impact of sedentarism due to the COVID-19 home confinement on neuromuscular, cardiovascular and metabolic health: Physiological and pathophysiological implications and recommendations for physical and nutritional countermeasure. Eur J Sport Sci 2020;12:1-22.

23. Mury P, Faes C, Millon A, Mura M, Renoux C, Skinner S et al. Higher daily physical activity level is associated with lower $\mathrm{RBC}$ aggregation in carotid artery disease patients at high risk of stroke. Front Physiol 2017;8:1043.

24. Toth K, Kesmarky G, Alexy T. Clinical significance of hemorheological alterations. In: Baskurt OK, editor. Handbook of hemorheology and hemodynamics. Amsterdam: IOS Press; 2007. p.392-432.

25. Stubbs R J, Hughes DA, Johnstone AM, Horgan GW, King $\mathrm{N}$, Blundell JE. A decrease in physical activity affects appetite, energy, and nutrient balance in lean men feeding ad libitum. Am J Clin Nutr 2004;79(1):62-9. 